Situmorang, N.Z., Muhipilah, P., Nasywa, N., \& Missasi, V. (2020). Depiction of trust in mother. Indigenous: Jurnal Ilmiah Psikologi, 5(2). 231-238. doi: https://doi.org/10.23917/indigenous. v5i2.11408

\title{
Depiction of Trust in Mother
}

\author{
Nina Zulida Situmorang ${ }^{1}$, Pipih Muhopilah' ${ }^{2}$ Naila Nasywa ${ }^{3}$, Vallahatullah Missasi ${ }^{4}$ \\ Magister Psikologi, Universitas Ahmad Dahlan ${ }^{1,2,3,4}$ \\ nina.situmorang@psy.uad.ac.id', pipihmuhopilah7@gmail.com², \\ nailanasywa21@gmail.com ${ }^{3}$, vallahatullahMissasi@yahoo.com ${ }^{4}$
}

\begin{tabular}{|l|l|l|}
\hline Submitted: 17 October 2020 & Accepted: 23 November 2020 & Published: 1 January 2021 \\
\hline
\end{tabular}

\begin{abstract}
Mother is person who very close to her child, mother always caring and pay attention, this closeness creates child's trust to his mother. Trust is what makes children feeling that the mother is the most comfortable people to share all their complaints without demeaning. This study aims to explore the child's closeness with his mother and the reason. This research used qualitative research with constructive realism method, the subject of this research are 60 students that aged 20-28 years, the subject was asked: "how close to his mother and made a reason why the subject was close to his mother?". FGD was conducted on six-person subjects, and open interviews with 1 subject, data analysis using categorization method. The results of this study indicate that there are 6 categories of reasons children believe to mothers, which are caring (20.57\%), understanding (20\%), sincere (18\%), attention (17.67\%), patient (9.67\%), resilient $(9.35 \%)$ and others (4.74\%). The FGD results and interviews show that the main reason for child trust is mother caring and understanding, caring is shown by always trying to meet the children needs, giving a good example, and giving the best to his family. Understanding from mother makes child tell various things and accepted.
\end{abstract}

Keywords: caring; mother; trust; understanding.

\section{INTRODUCTION}

Early adulthood (18-40 years) is the period when individuals experience developmental tasks, namely applying for a job, choosing a partner, being separated from parents, independent, and responsible (Desmita, 2015). In Indonesia, adults have another moral obligation, which is being devoted children to their parents though it does not exist in various concepts of adult development tasks. Being devoted to parents is an effort to repay the kindness that has been given by parents, or reciprocation of the kindness by parents. A reciprocal relationship is a connection largely based on trust. The foundation of trust in others convince individuals to engage in reciprocal relationships and accept the consequences (Johnson \& Cullen, 2017).

The closest relationship between human beings is the relationship between children and mothers (Arif, 2016). The quality of the parents-children relationship affects children's efforts to seek and maintain closeness, support, and trust from mothers (Bosmans et al., 2015). The presence of trust between mothers and children create meaning in their relationship (Johnson \& Cullen, 2017).

Trust is essential in a relationship, trust is the basis for the exchange or mutual giving. Trust allows individuals to be influenced by others. Trust continues developing all the time, and necessary 
to be in presence prior to any exchange activity (Johnson \& Cullen, 2017). The three foundations of interpersonal trust are believing that others are keeping their promises; honesty, when the other is telling the truth and engaging in guided behavior; and emotion, which is believing that the others restrain themselves emotionally (Rotenberg et al., 2015).

Departing from the importance of trust, the researchers are interested in understanding how adults trust their mothers by exploring the cause of having trust in mothers.

\section{METHOD}

This is qualitative research using the constructive realism method. Constructive realism is a method that attempts to synthesize the existing paradigms in social science (Kim, Yang \& Hwang, 2006; Allwood, 2019). In this study, researchers conducted three methods of data collection. First, participants filled out questionnaires, which were taken based on the questionnaires by Kim, Yang and Hwang (2006). The questionnaire contains "how close are you to your mother?" and "write down five words why you trust your mother and explain why". Second, a focus group discussion was held asking "how close are you to your mother?", "what does mother mean to you?" and "why do you trust your mother?". Third, an in-depth interview was conducted using the same questions as those in the focus group discussion.

Participants were 60 students in Yogyakarta aged 20-28 years, comprising 20 men and 40 women. Questionnaires were administered to 60 participants, focus group discussion involved 6 participants, and 1 participant followed in-depth interview. After collecting, the data were processed by conducting a content analysis. The researchers carried out thematic analysis based on the keywords obtained, then performed coding so that the data collected based on the theme could be transformed into an understanding.

\section{RESULTS AND DISCUSSION}

\section{Data Description}

Table 1.

Participants' Trust in Mother based on Gender

\begin{tabular}{cccc}
\hline No & Sex & F & $\%$ \\
\hline 1 & Male & 20 & 33,33 \\
2 & Female & 40 & 67,67 \\
\hline Total & & 60 & 100 \\
\hline
\end{tabular}

Table 2.

Participant Closeness to Mother

\begin{tabular}{cccc}
\hline & Closeness & F & $\%$ \\
\hline & Very Close & 42 & 70 \\
& Close & 14 & 22,33 \\
& Quite close & 3 & 5 \\
& Less close & 1 & 1,67 \\
& Not at all & - & - \\
\hline Total & & 60 & 100 \\
\hline
\end{tabular}


Participants in this study consisted of 60 participants and most of them were female. Furthermore, this section will present participants' answers to the open questionnaire questions. Table 2 shows the distribution of participants' answers to the question "How close are you to your mother?" The results show that most of the participants (70\%) answered very close to the mother.

Table 3 shows the answers to the open questionnaire "why do trust in your mother". The results describe 6 reasons why participants trust their mothers. The category with the most number is caring with a percentage of 20.67 .

Table 3.

Reasons for Participants to Trust Mother

\begin{tabular}{ccccc}
\hline & No & Category & F & $\%$ \\
\hline & 1 & Caring & 62 & 20,67 \\
& 2 & Understanding & 60 & 20 \\
& 3 & Sincerity & 54 & 18 \\
& 4 & Attention & 53 & 17,67 \\
& 5 & Patience & 29 & 9,67 \\
& 6 & Toughness & 28 & 9,33 \\
& 7 & Others & 14 & 4,67 \\
\hline Total & & 300 & 100 \\
\hline
\end{tabular}

\section{Results of the open questionnaire, Focus Group Discussion, and Interview}

FGD and interview were conducted to support the results of the open questionnaire, which is to find more complete reasons why this phenomenon occurred. Based on FGD and interview conducted by researchers with participants, researchers found several reasons why participants trust their mothers. These results reinforce the results of the open questionnaire.

Caring. Based on the results of the open questionnaire, Caring obtained the largest percentage with $20.67 \%$. Caring is shown by always fulfilling the needs of their children without any excuses. Also, mothers always show a good example to their children, protect, take care of family, and always give the best. Based on the results of FGD and interview, it was also found why the answer to "why do trust your mother" is caring in the following excerpts:

1) Mothers always give the best for their children: “... Because she is a mother and surely mother will do what is the best for her child" (L, W1; L250-252).

2) Mothers always give a good example for their children: The reason why participants trust their mothers is that their mothers are Muslims who would give a good example in worship and it is for the sake of Allah.

The reason why I believe in my mother because she is a true Muslim who truly worships and everything she does is for the sake of worshiping Allah and I want to be like her. This what makes me trust my mother ... (R, W1; L268-275).

Definition. Based on the results of the open questionnaire, the understanding category obtained a percentage of $20 \%$. The reason was that mothers are the place for their children to tell everything, complain about problems they experience, and mothers are the place to tell stories and complain. Mothers are very trustworthy, will keep secrets, and always accept their children the way they are without asking them to be someone else. It is reinforced by the results of the FGD and interview showing that the understanding is the reason for "why do you trust your mothers": 
1) Mothers are the place for their children to tell everything

Participants stated that they and their mothers are open to each other and often tell things to each other, "... tell everything to my mother and share it together" (R.J, W2; L 56-60).

Always tell anything to mothers, "... I always tell everything to my mother" (R.J, W2; L 94-95).

Be open with mothers about relationships with their surrounding, “... I am always open with my mother about my relationships with people around me” (R.J, W2; L 110-113).

Regardless of the problem, always tell mothers, "... I always tell my mother any problem " (L, W1; 114-115).

Tell things to mothers without anything hiding anything, "... I talk to my mother without covering up any problem" (L.W1; 120-121).

2) Mothers never ask their children to be someone else and always accept them the way they are $M$ others never ask their children to act like them but it is their nature that children want to be like their mothers, ".... My mother never asks me to be like her but it is her nature that makes me want to be like her without realizing it."(R, W1; L284-291)

M others ask to maintain trust given to their children without asking for anything, "... My mother only asks me to maintain the trust she gave me without asking anything from me" (R.J, W2; L 184-188).

Sincerity. Based on the results of the open questionnaire, sincerity earned $18 \%$. Sincerity is the ability of mothers to do good and pour out love for their children, forgive their children's mistakes, do something selflessly, show a kind attitude, and care for their children and others. It is supported by the results of the FGD and interview showing that sincerity is the reason for "why do you trust your mother":

1) Sincerity. The most sincere human being is mother, "... The most sincere human beings are our parents" (R, W2; L 141-142).

2) Mothers always forgive mistakes either children's fault or someone else's. Mothers always teach to forgive others and always respect others in any circumstances, "... My mother always teaches me to forgive others and always respect in any circumstances" (R.J, W2; L 128).

3) Mothers always pour out love for their children. Mothers always wake up at the midnight to pray for their children, "... My mother always wakes up in the midnight to pray the best for their children" (S, W1; L331-333).

Attention. The other reason for filling out the question of "why do you trust your mother?" is attention. The attention has a percentage of $17.67 \%$. Furthermore, based on an open questionnaire, mothers' attention is always shown by frequently asking their children, advising for the good of their children, and supporting every activity and decision that their child makes. It is following the results of FGD and interview as presented in the following excerpts:

1) Mothers show their attention by frequently asking their children's condition. Mothers never get tired of calling their children and asking about their condition, whether physics or spiritual state, "... never gets tired of calling her child and asks condition, whether physically or spiritually good." (S, W1;25-28).

2) Mothers display attention by advising their children

$M$ others always remind their children not to abandon prayer, to forgive others, to respect others, and to be grateful, "... Always reminds to always pray, and to always forgive others, respect others, and always be grateful whatever the situation is." (R.J, W2; L 126-129).

$M$ others always give positive energy, strengthen, and give extraordinary support, "Mother always gives positive energy and always strengthens and gives extraordinary support." (I, W1; L265-267) 
3) Mothers always guide their children. Mothers always want the best for their children. According to the participants, mothers always help in making a decision. Participants always ask for their mothers' opinions even though it is a simple matter because they will feel relieved, "... Always ask mother's opinion even though it is a simple matter, if I haven't talked to my mother, my heart will remain restless." (I, W1; 150-155)

4) Mothers always provide support to their children. What mothers do to show their supports for their children's choices is to believe in and ask their children to always maintain the trust they have given.

M other and I have an agreement, which is to maintain the trust she gives me, " Mother and I have an agreement, which is to maintain the trust she gives me." (R.J, W2; L 158-161)

If I do any activity, my mother always permits as long as it is a good act and does not harm others, "If I do any activity, mother always permits as long as it is a good act and does not harm others." (M, W1; L307-310)

Patience. Based on the results of an open questionnaire, the next reason "why do you trust your mother?" is patience. Patience has a percentage of $9.67 \%$. The result shows that mothers can always hold back their emotions towards their children's behavior. Also, mothers always hold back their desires to achieve their children's. Mothers are able to survive in difficult situations, never complain, and accept life as is. It is according to the results of the FGD and interview. The followings are excerpts from the interview results: Participants expressed the reason for trusting their mothers is because mothers are always patient with all the attitudes of their children, accept as they are, and always pray for their children, "The reason why I trust my mother is that she is always patient with all her children's attitudes, she always accepts us, prays for us all the time, and wishes us all the best..." (S, W1; L316-322)

Toughness. Based on the results of an open questionnaire, the next reason for "why do you trust your mother?" is toughness. Toughness shows a percentage of $9.33 \%$. Based on the answers to the open questionnaire, mothers are very independent, strong, hardworking, protective, and willing to do anything for their families. It is in accordance with the results of the FGD and interview. The excerpts below are from the interview results:

1) Mothers are hard workers. Mother cannot pick me up at school because she has to work and earns money for us, “...Mother cannot pick me up at school because she has to work and earns money for us.” (S, W1; L256-260).

2) Mothers always help their family. Mothers are wise individuals and always help their siblings, "... Mother is a wise person and always helps her siblings" (R, W1; L279-282).

The results show that $70 \%$ of the participants were very close to their mothers. It shows that adults feel closeness and warmth to their mothers. The mother-child closeness shows that there is a concept of closeness that is similar to the concept of human heartedness that develops in East Asia. This concept states that there is a reciprocal relationship between parent and child, this relationship is passed through the existence of love, sacrifice, and devotion (Kim, Yang \& Hwang, 2006).

The closeness to the mother emerges good intention so that the child develops the belief that a mother is a person who is not dangerous, cares, and always fulfills her obligations as a mother. The family structure strongly supports the closeness and relationship of mother and child so it becomes a connection (Magnus et al., 2016). The experience of good relationships will make individuals learn to trust others, experiences make individuals have information about what to do, and the consequences of certain behavior (Johnson \& Cullen, 2017). Although the participants in this research were not specifically taken from those coming from the same ethnic group, the 
concept of trust in mothers is generally the same. It is consistent with previous research stating that the phenomenon of trust is meaningful in all cultures and it is an important thing to build an interpersonal relationship (Seok et al., 2015).

The children's trust in their mother continues to develop through the presence of specific situations, uncertain risk conditions, feelings of security, and trust. Trust is defined as the willingness to depend or expectation to depend on others, which on the other hand will create a sense of security though it means that the individual will lack the ability to control oneself and allow negative consequences of that trust. Trust is a decision to take action, instead of holding hope, it extends the size to a higher one (Zhong et al., 2017). Trust in the mother is also formed because of these aspects, it is indicated by the highest reason that children trust their mother as mothers are caring and understanding figures.

Mother's caring is displayed by always fulfilling the needs of her child regardless of anything. Mother always gives a good example to her child, cares, takes care of family, and gives the best for her family. Fulfilling the needs of the child implies that the mother still provides material support, even though her child is already an adult. It is shown by providing many things her child desires in material, whether for learning purpose or other things. Giving good examples to her child depicts mothers as models for their children. For instance, in worship, mothers provide examples of good and correct worship act. A mother's caring and attention for her child is positively associated with the child's trust in the mother, with good communication as a medium of association (Ying et al., 2015). Mother's attention to participants is shown by always contacting participants as the majority of participants did not live with parents because due to the education process.

Mother is an understanding figure so she is the place for her child to tell everything, to complain about problems being experienced, and mother is the place to tell stories and complain because she is a trustworthy person, keeps secrets, and always accepts child without asking to be someone else. Mother as a place to tell stories for children will form open communication between mother and child so that it will contribute to the affective quality between mother and child, in which its qualities and good communication will form good trust (Ying et al., 2015). The mother's acceptance of the child as is and without demanding will stimulate the child to express his emotions openly to the mother, without fear that the mother will not accept it.

In general, the results of this study are in line with previous research conducted by Putri (2018) which reveals that mother's parenting greatly affected the acceptance and appreciation of the child, the attachment between mother and child is formed before five years old so that it will greatly impact the social relationships that will occur in the future.

Warmth, control, intimacy, and praise given to children are parenting styles of a mother that create an attachment to children (Xu et al., 2005).

Indrawan anda Aprianti (2019) affirm that verbal communication used by mothers to children has properties that make children feel comfortable with every word spoken. Non-verbal communication messages that mothers and children apply often use paralinguistic messages and touch messages to support the process of building trust.

Research by Elfida and Hidayat (2013) shows that the reason participants trust their mother is because of the mother's character (38.05\%), role (30.24\%), relations (22.93\%), and reliability (8.778\%). Research by Fernando and Elfida (2018) discovers that there are six reasons for closeness to the mother, namely emotional bonding ( $73.6 \%$ of all participants), mother's role $(11.2 \%)$, respect (5.8\%), support (3.4\%), blood ties (3.2\%), and mother as a figure $(2.8 \%)$.

Trust in parents creates devotion in children to serve them good. It is an effort to repay the kindness of children. According to Kim, Yang and Hwang (2006), parental sacrifice is the 
foundation of trust that grows in children. It makes children care for their parents and be devoted to their parents.

This study has limitations. First, there is an imbalance in the ratio of the number of male and female participants, where male participants were less than female. Second, the researchers did not explain the family background factors, including ethnicity, religion, and income, which will be an important factor because these factors will determine how the relationship between mother and child is perceived and carried out in everyday life. For the next research, it is better to find other aspects that affect the child's trust in the mother as described above.

\section{CONCLUSION}

Trust is essential in a relationship, trust is the foundation of reciprocal relationships experienced by individuals, including the relationship between mother and child. The child's trust in the mother will create a sense of devotion of the child to the mother even though it is not part of the adult development task. In Indonesia, children want to be devoted to their parents as shown in this study, $70 \%$ of the participants were very close to the mother. Closeness led to the child's trust in the mother and the willingness to serve the mother. The child's trust in the mother occurs because the mother is an individual who is a caring, understanding, sincere, attentive, patient, and resilient person. In general, the results of this study are consistent with previous research.

\section{REFERENCES}

Allwood, C. M. (2019). Future prospects for indigenous psychologies. Journal of Theoretical and Philosophical Psychology, 39(2), 90-97. https://doi.org/10.1037/teo0000108

Arif, I. S. (2016). Psikologi positif: Pendekatan saintifik menuju kebahagiaan. Jakarta: Gramedia Pustaka Utama.

Bosmans, G., Braet, C., Heylen, J., \& De Raedt, R. (2015). Children's attentional processing of mother and proximity seeking. Plos One, 10(4), e0124038. https://doi.org/10.1371/ journal.pone. 0124038

Desmita. (2015). Psikologi perkembangan. Bandung: PT Remaja Rosdakarya.

Elfida, D., \& Hidayat, H. (2013). Trust toward father and mother: An indigenous psychology analysis on children's trust toward parents. Psikologika: Jurnal pemikiran dan penelitian psikologi, 18(1), 51-58. https://doi.org/10.20885/psikologika.vol18.iss1.art6

Fernando, T., \& Elfida, D. (2018). Kedekatan remaja pada ibu: pendekatan indigenous psychology. Jurnal Psikologi, 13(2), 150. https://doi.org/10.24014/jp.v13i2.3081

Indrawan, Y., \& Aprianti, A. (2019). Komunikasi interpersonal orang tua dan anak tiri dalam membangun kepercayaan. E-Proceding of Management, 6(2), 1-13. Retrieved from https:// core.ac.uk/download/pdf/299930864.pdf

Johnson, J. L., \& Cullen, J. B. (2017). Trust in cross-cultural relationships. In Gannon, M.J \& Newman, K.L (Eds.). The blackwell handbook of cross-cultural management (pp. 335-360). New Jersey, US: Blackwell Publishing Ltd. https://doi.org/10.1002/9781405164030.ch17 
Kim, U., Yang, K. S., \& Hwang, K. K. (2006). Indigenous and cultural psychology: Memahami orang dalam konteksnya. Yogyakarta: Pustaka Pelajar.

Magnus, P., Birke, C., Vejrup, K., Haugan, A., Alsaker, E., Daltveit, A. K., Handal, M., Haugen, M., Høiseth, G., Knudsen, G. P., Paltiel, L., Schreuder, P., Tambs, K., Vold, L., \& Stoltenberg, C. (2016). Cohort profile update: The Norwegian mother and child cohort study (MoBa). International Journal of Epidemiology, 45(2), 382-388. https://doi.org/10.1093/ije/dyw029

Putri, D. O. D. T. (2018). Pengaruh Kelekatan (Attachment) Orang Tua terhadap Kepercayaan Diri pada Remaja (Skripsi, Universitas Muhammadiyah Malang, Malang). Retrieved from http://eprints.umm.ac.id/41431/1/Skripsii\%20cover\%20sampai\%20lampiran.pdf

Rotenberg, K. J., Woods, E. E., \& Betts, L. R. (2015). Development of a scale to assess children's trust in general nurses. Journal for Specialists in Pediatric Nursing, 20(4), 298-303. https:// doi.org/10.1111/jspn. 12126

Seok, C. B., Mutang, J. A., \& Hashmi, S. I. (2015). Trust formation to the mother: A comparison between male and female adolescents. Procedia - Social and Behavioral Sciences, 171, 299308. https://doi.org/10.1016/j.sbspro.2015.01.126

Xu, Y., Farver, J. A., Zhang, Z., Zeng, Q., Yu, L., \& Cai, B. (2005). Mainland Chinese parenting styles and parent-child interaction. International Journal of Behavioral Development, 29(6), 524-531. https://doi.org/10.1177\%2F01650250500147121

Ying, L., Ma, F., Huang, H., Guo, X., Chen, C., \& Xu, F. (2015). Parental monitoring, parentadolescent communication, and adolescents' trust in their parents in China. Plos One, 10(8), 1-9. https://doi.org/10.1371/journal.pone.0134730

Zhong, W., Su, C., Peng, J., \& Yang, Z. (2017). Trust in interorganizational relationships. Journal of Management, 43(4), 1050-1075. https://doi.org/10.1177/0149206314546373 